\title{
Thermal stability of imidazolium-based ionic liquids
}

\author{
Léa Chancelier $^{\mathrm{a}}$, Olivier Boyron ${ }^{\mathrm{a}}$, Thibaut Gutel ${ }^{\mathrm{b}}$, Catherine C. Santini ${ }^{*}$ \\ ${ }^{a}$ UMR CNRS 5265, C2P2, University of Lyon, 43 bd du 11 novembre 1918, F-69100 Villeurbanne \\ ${ }^{\mathrm{b}}$ CEA, LITEN, 17 rue des martyrs, F-38000 Grenoble
}

catherine.santini@univ-lyon1.fr

Keywords: thermal stability, anion effect, alkyl chain length, functionalization, ionic liquids.

This work highlights the factors tuning the thermal stability of imidazolium-based ionic liquids (IL) associated to bis(trifluoromethanesulfonyl)imide anion $\left[\mathrm{NTf}_{2}\right]$. The decomposition temperatures $\left(\mathrm{T}_{\mathrm{d}}\right)$ are evaluated by thermogravimetric analyses (TGA) with optimised parameters to obtain reproducible $\mathrm{T}_{\mathrm{d}}$. The impact of the alkyl chain length and of the presence of functional groups and unsaturations on $T_{d}$ are evaluated. The thermal behavior is governed by Van der Waals interactions between alkyl chains, and by inter and intra coulombic interactions such as hydrogen bonds.

\section{Introduction}

Ionic liquids (IL) are defined as molten salts, liquid at room temperature or at least below $100{ }^{\circ} \mathrm{C}$. Such low melting points result from the association of an organic cation with delocalised charge to a weakly coordinating organic or inorganic anion.[1] The combination of a broad variety of cations and anions theoretically allows to form as many as $10^{6} \mathrm{IL}$. Hence, a wide diversity in IL structure is possible, and by modifying either the cationic or the anionic component of an IL, their physical properties such as melting point, viscosity, thermal stability, solubility and hydrophobicity can easily be finetuned.[2, 3]

Due to the quite strong coulombic interactions within these substances, IL fulfill all conditions required by green solvents. Unlike most organic solvents, they do not evaporate unless heated to the point of thermal decomposition, typically 200-300 ${ }^{\circ} \mathrm{C}$.[1] They have flash points higher than $200{ }^{\circ} \mathrm{C}$ and can be considered as flame retardants.[4-8] In addition to this very interesting combination of properties, they are excellent solvents which may be immiscible with water or organic solvents affording biphasic systems with them. Moreover, they may exhibit very large electrochemical windows. Keeping in mind the principles of green chemistry, IL have attracted much attention in the scientific community (chemists, biologists, and others) during the past two decades.[1, 9] They have consequently been considered for a variety of applications such as separation technology,[10, 11] catalysis,[12-14] biomass treatment $[15,16]$ and energy storage.[1, 9, 17, 18]

For industrial applications of IL as alternative green solvents, the determination of both 
decomposition and melting temperatures is of paramount importance. These properties determine the liquid range of the compounds, and consequently their range of application.

Among all IL, we focused our study on the imidazolium-based $\mathrm{IL}\left[\mathrm{C}_{1} \mathrm{C}_{\mathrm{n}} \mathrm{Im}\right]$, Figure 1 , as these cations can be easily chemically modified.[1, 9, 19] The $\mathrm{T}_{\mathrm{d}}$ of typical imidazolium-based IL are collected in Table 1.

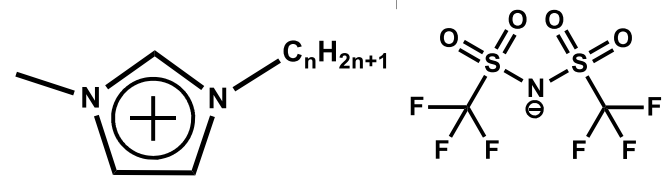

Figure 1. Alkylmethylimidazolium cation $\left[\mathrm{C}_{1} \mathrm{C}_{\mathrm{n}} \mathrm{Im}\right]$ and bis(trifluoromethanesulfonyl)imide anion $\left[\mathrm{NTf}_{2}\right]$

Table 1. $T_{d}$ values of typical IL depending on cation and anion natures. The onset temperatures are reported in roman font and start temperatures in italic type. Bold characters stand for inert atmosphere (nitrogen or argon), and the data are underlined depending on the heat rate as follow: $\underline{\underline{5^{\circ} \mathrm{C} \cdot \mathrm{min}^{-1}}}, \quad 10^{\circ} \mathrm{C} \cdot \mathrm{min}^{-1}, \quad 20^{\circ} \mathrm{C} \cdot \mathrm{min}^{-1}$ and no underlining when not available. $\mathrm{C}_{1} \mathrm{C}_{n} \mathrm{Im}$ : 1-alkyl-3methylimidazolium; $\quad \mathrm{C}_{1} \mathrm{C}_{1} \mathrm{C}_{\mathrm{n}} \mathrm{Im}$ : 1-alkyl-2,3dimethylimidazolium cation, and $\mathrm{C}_{1} \mathrm{C}_{1} \mathrm{C}_{1} \mathrm{C}_{1} \mathrm{C}_{1} \mathrm{Im}$ : 1,2,3,4,5-pentamethylimidazolium cation

\begin{tabular}{|c|c|c|c|c|}
\hline $\mathbf{T}_{\mathrm{d}}\left({ }^{\circ} \mathbf{C}\right)$ & $\mathrm{Cl}$ & $\mathbf{B F}_{4}$ & $\mathrm{PF}_{6}$ & $\mathbf{N T f}_{2}$ \\
\hline $\mathrm{C}_{1} \mathrm{C}_{1} \mathrm{Im}$ & & & & $\underline{\mathbf{4 4 4}}[20]$ \\
\hline \multirow[t]{9}{*}{$\mathrm{C}_{1} \mathrm{C}_{2} \mathrm{Im}$} & $\underline{\underline{278}}[21]$ & $300[23]$ & $\underline{190}[27]$ & $280[28]$ \\
\hline & 281[22] & $\underline{445}[24]$ & $\underline{\mathbf{2 7 3}}[27]$ & $\underline{\underline{358}}[29]$ \\
\hline & & $\underline{\mathbf{4 4 7}}[25]$ & $481[22]$ & $374[30]$ \\
\hline & & 450[22] & & $\underline{400}[31]$ \\
\hline & & $\underline{\mathbf{4 5 0}}[26]$ & & $\underline{410}[32]$ \\
\hline & & & & 411[33] \\
\hline & & & & $\underline{419}[34]$ \\
\hline & & & & $\underline{\mathbf{4 3 9}}[20]$ \\
\hline & & & & $\mathbf{4 5 3}[22]$ \\
\hline \multirow[t]{3}{*}{$\mathrm{C}_{1} \mathrm{C}_{3} \mathrm{Im}$} & 269[35] & 393[35] & 440[22] & 453[22] \\
\hline & 281[22] & $\underline{\mathbf{4 3 5}}[25]$ & & \\
\hline & & $\underline{\mathbf{4 5 0}}[26]$ & & \\
\hline \multirow[t]{10}{*}{$\mathrm{C}_{1} \mathrm{C}_{4} \mathrm{Im}$} & $\underline{150}[36]$ & $\underline{\mathbf{2 8 0}}[40]$ & $300[28]$ & $275[28]$ \\
\hline & $173[37]$ & $\underline{290}[36]$ & $\underline{315}[42]$ & $\underline{\mathbf{3 3 0}}[36]$ \\
\hline & $\underline{193}[38]$ & $300[28]$ & $\underline{\mathbf{4 3 3}}[41]$ & $\underline{\mathbf{3 9 1}}$ [43] \\
\hline & $202[37]$ & $\underline{\mathbf{3 6 1}}[36]$ & $\underline{\mathbf{3 4 9}}[39]$ & $\underline{422}[36]$ \\
\hline & $\underline{\mathbf{2 3 4}}[32]$ & 380[35] & & $\underline{\mathbf{4 2 3}}[41]$ \\
\hline & $\underline{\text { 254[39] }}$ & $\underline{\mathbf{4 0 3}}[39]$ & & $\underline{\mathbf{4 2 7}}[20]$ \\
\hline & $\underline{\mathbf{2 6 4}}[36]$ & $\underline{424[24]}$ & & $\underline{\mathbf{4 3 9}}[39]$ \\
\hline & $268[35]$ & $\underline{\mathbf{4 2 5}}[41]$ & & $\underline{\underline{461}}[21]$ \\
\hline & $\underline{\underline{291}}[21]$ & $\underline{435}[25]$ & & \\
\hline & & $\underline{\mathbf{4 5 0}}[26]$ & & \\
\hline $\mathrm{C}_{1} \mathrm{C}_{5} \mathrm{Im}$ & 262[35] & 408[35] & & \\
\hline \multirow[t]{4}{*}{$\mathrm{C}_{1} \mathrm{C}_{6} \mathrm{Im}$} & $\underline{\mathbf{2 5 3}}[39]$ & $\underline{262}[44]$ & $\underline{\mathbf{3 2 0}}[44]$ & $275[28]$ \\
\hline & & $\underline{\mathbf{4 2 5}}[44]$ & $\underline{417}[39]$ & $\underline{302}$ [44] \\
\hline & & & $\underline{\mathbf{4 5 4}}[44]$ & $\underline{\mathbf{4 2 8}}[20]$ \\
\hline & & & & $\underline{\mathbf{4 6 1}}[44]$ \\
\hline \multirow[t]{2}{*}{$\mathrm{C}_{1} \mathrm{C}_{8} \mathrm{Im}$} & $\underline{\mathbf{2 4 3}}[39]$ & & $\underline{\mathbf{3 7 6}}[39]$ & $\geq 300[45]$ \\
\hline & & & & $\underline{\mathbf{4 2 5}}[20]$ \\
\hline $\mathrm{C}_{1} \mathrm{C}_{16} \mathrm{Im}$ & $\underline{\mathbf{2 3 0}}[32]$ & & & \\
\hline $\mathrm{C}_{1} \mathrm{C}_{1} \mathrm{C}_{2} \mathrm{Im}$ & $290[22]$ & & 500[22] & 456[22] \\
\hline \multirow[t]{3}{*}{$\mathrm{C}_{1} \mathrm{C}_{1} \mathrm{C}_{3} \mathrm{Im}$} & $\underline{\mathbf{2 6 0}}[32]$ & $\underline{\mathbf{3 9 0}}[32]$ & 399.[22] & $\underline{\mathbf{3 8 5}}[36]$ \\
\hline & 284[22] & 457[24] & & 462[22] \\
\hline & & & & $\underline{462}[36]$ \\
\hline \multirow[t]{7}{*}{$\mathrm{C}_{1} \mathrm{C}_{1} \mathrm{C}_{4} \mathrm{Im}$} & $\underline{\mathbf{2 5 7}}[32]$ & $\underline{285}[36]$ & $\underline{\mathbf{2 3 5}}[36]$ & \\
\hline & & $\underline{\underline{\mathbf{3 4 7}}}[38]$ & $\underline{\underline{\mathbf{3 4 7}}}[38]$ & \\
\hline & & $\underline{\underline{\mathbf{3 6 4}}}[46]$ & $\underline{\mathbf{3 7 3}}[36]$ & \\
\hline & & $\underline{\mathbf{3 8 0}}[36]$ & $\underline{\mathbf{4 2 5}}[32]$ & \\
\hline & & $\underline{\mathbf{3 9 8}}[46]$ & & \\
\hline & & $\underline{\mathbf{4 0 5}}[32]$ & & \\
\hline & & 428[46] & & \\
\hline $\mathrm{C}_{1} \mathrm{C}_{1} \mathrm{C}_{10} \mathrm{Im}$ & $\underline{\mathbf{2 3 9}}[32]$ & $\underline{\mathbf{4 0 0}}[32]$ & $\underline{\mathbf{4 2 0}}[32]$ & \\
\hline $\mathrm{C}_{1} \mathrm{C}_{1} \mathrm{C}_{16} \mathrm{Im}$ & $\underline{\mathbf{2 3 9}}[32]$ & $\underline{\mathbf{4 0 0}}[32]$ & $\underline{400}[32]$ & \\
\hline $\mathrm{C}_{1} \mathrm{C}_{1} \mathrm{C}_{20} \mathrm{Im}$ & & $\underline{\mathbf{3 9 0}}[32]$ & & \\
\hline $\mathrm{C}_{1} \mathrm{C}_{1} \mathrm{C}_{1} \mathrm{C}_{1} \mathrm{C}_{1} \mathrm{In}$ & & & 487[22] & 466[22] \\
\hline
\end{tabular}


The $\mathrm{T}_{\mathrm{d}}$ of these imidazolium-based IL are mainly dependent on the nature of the anion. Whatever the cation, halide-derivated IL always show the lowest $\mathrm{T}_{\mathrm{d}}$, and fluorinated anions show the highest.[47-51] The observed stability order is: $\mathrm{NTf}_{2}>\mathrm{PF}_{6} \geq \mathrm{BF}_{4}>\mathrm{Cl}$, Table 2. IL containing weakly coordinating anions (less nucleophilic) are generally the most stable.[1, 52-54] The most common decomposition mechanism is the formation of alkyl-halide species by $S_{N} 1$ and $S_{N} 2$ nucleophilic substitution mechanisms,[55, 56] underlining the importance of the size, the basicity and the nucleophilicity of the anion. The IL stability is consequently inversely proportional to the stability of these alkyl-halides.[49, 52, 57]

This work is focused on $\mathrm{NTf}_{2}$ anion, also called TFSI, BTA or TFSA, Figure 1, affording liquid products at room temperature in most cases. Furthermore, it provides high thermal stability and its hydrophobicity allows efficient purification by removal of salts in water, which is required e.g. for lithium-ion batteries application.[1] This anion also prevents from HF generation observed with $\mathrm{BF}_{4}$ or $\mathrm{PF}_{6}$ anions in the presence of water.[57] Note that the decomposition of $\mathrm{NTf}_{2}$ anion is exothermic, and releases $\mathrm{SO}_{2}$ gas.[57]

\begin{tabular}{l}
\hline \multicolumn{1}{c}{ Stability orders } \\
\hline $\mathrm{PF}_{6}>\mathrm{BETI}_{\mathrm{NTf}} \approx \mathrm{BF}_{4} \gg \mathrm{I} \approx \mathrm{Br} \approx \mathrm{Cl}[22]$ \\
$\mathrm{OTf}_{2}>\mathrm{BF}_{4}>\mathrm{PF}_{6}>\mathrm{Br}>\mathrm{NO}_{3}[54]$ \\
$\mathrm{NTf}_{2}>\mathrm{PF}_{6}>\mathrm{BF}_{4}[44]$ \\
$\mathrm{NTf}_{2}=\mathrm{OTf}>\mathrm{dca}>\mathrm{SCN}[45]$ \\
$\mathrm{NTf}_{2}>\mathrm{OMs}_{\mathrm{O}} \approx \mathrm{Tcm} \approx \mathrm{dca}[58]$ \\
$\mathrm{NTf}_{2}>\mathrm{PF}_{6}>\mathrm{BF}_{4}>\mathrm{OMs}>\mathrm{OTf}>\mathrm{I}>\mathrm{Cl}[47]$ \\
$\mathrm{BF}_{4}>\mathrm{Cl} \sim \mathrm{I}[35]$
\end{tabular}

Table 2. Stability orders of different anions associated to imidazolium cations; dca: $\mathrm{N}(\mathrm{CN})_{2}, \mathrm{Tcm}: \mathrm{C}(\mathrm{CN})_{3}$

It is admitted that due to their extremely low vapor pressure, the upper limit of liquid range of IL is their $T_{d}$. [1] $T_{d}$ are generally determined by thermogravimetric analysis (TGA) where the mass of a sample is monitored during an increase of temperature (with constant heating rate), in a controlled atmosphere. The mass loss is related to the formation of volatile species which are extracted by the gas flow. Thus, $\mathrm{T}_{\mathrm{d}}$ are determined only when such species are formed during the decomposition of the product. Another limit is the possible IL vaporisation, influencing also the mass loss, which is detrimental for protic IL and IL containing volatile anion such as acetate.[59, 60]

In this work, we performed temperature-ramped or scanning TGA, for which $\mathrm{T}_{\mathrm{d}}$ value is known to vary significantly with experimental conditions including heating rate, carrier gas nature and flow rate, pan nature and sample purity. Thus, only $\mathrm{T}_{\mathrm{d}}$ determined under identical experimental conditions can be compared.[4, 24, 36, 46, 6164] e.g. in the literature the value of onset $\mathrm{T}_{\mathrm{d}}$ of 1-butyl-3-methyl-imidazolium

bis(trifluoromethanesulfonyl)imide $\quad\left[\mathrm{C}_{1} \mathrm{C}_{4} \mathrm{Im}\right]$ [NTf $\mathrm{Naries}_{2}$ by more than $150^{\circ} \mathrm{C}$, Table 3 . 


\section{$\begin{array}{llllllll}T_{\mathbf{d}} & 275 & \underline{\mathbf{3 9 1}} & \underline{\mathbf{4 2 2}} & \underline{\mathbf{4 2 7}} & \underline{\mathbf{4 2 7}} & \underline{\mathbf{4 3 9}} & \underline{461} \\ \left({ }^{\circ} \mathrm{C}\right) & & \end{array}$}

$\begin{array}{llllllll}\text { Ref. } & {[28]} & {[43]} & {[36]} & {[20]} & \text { a } & {[39]} & {[21]}\end{array}$

Table 3. Decomposition temperatures reported in the literature for $\left[\mathrm{C}_{1} \mathrm{C}_{4} \mathrm{Im}\right]\left[\mathrm{NTf}_{2}\right]$; ${ }^{\text {a }}$ this work; $\underline{\underline{5}{ }^{\circ} \mathrm{C} \cdot \mathrm{min}^{-1}}$, $\underline{10^{\circ} \mathrm{C} \cdot \mathrm{min}^{-1}}$ or $20^{\circ} \mathrm{C} \cdot \mathrm{min}^{-1}$, no underlining when unspecified; bold for inert gases $\left(\mathrm{N}_{2}\right.$ and $\left.\mathrm{Ar}\right)$

This discrepancy results from the use of different definitions of $\mathrm{T}_{\mathrm{d}}$ and different experimental parameters. In order to compare $\mathrm{T}_{\mathrm{d}}$ of different IL, we standardize the experimental parameters. Firstly, the possible definitions of $\mathrm{T}_{\mathrm{d}}$ (start, onset and peak temperatures) are explained. Then the major experimental parameters affecting $T_{d}$ values are optimised in order to obtain reproducible $T_{d}$. Once the set of parameters are selected, the evolution of $T_{d}$ with the nature of the alkyl chain linked to imidazolium ring is studied.

\section{Results and discussion}

\section{Experimental parameters for TGA}

\subsection{Decomposition temperatures definitions}

Several definitions for decomposition temperatures $\left(\mathrm{T}_{\mathrm{d}}\right)$ are reported, including start, onset, $\mathrm{x} \%$ mass loss, and peak temperatures. The start temperature $\left(\mathrm{T}_{\text {start }}\right)$ is the temperature at which the sample starts to lose mass.[36] It is the temperature at which the first derivative of the weight loss $v s$ temperature $|\mathrm{dw} / \mathrm{dT}|$ is superior to $10^{-4} \mathrm{mg} \cdot \mathrm{s}^{-1}$. The associated uncertainty is $5{ }^{\circ} \mathrm{C}$. The $\mathrm{x} \%$ mass loss temperature is the temperature at which $1 \%, 5 \%$ or $10 \%$ of the mass are lost.[30, 32, 34, 43, 65-67] The peak temperature, or peak mass loss temperature, is defined as temperature at which the first derivative of the mass $v s$ temperature is the highest. This analysis gives results even up to $80^{\circ} \mathrm{C}$ higher than onset temperatures.[46]

The onset temperature ( $\mathrm{T}_{\mathrm{onset}}$ ) is generally defined by the tangent method, but also by the $5 \%$ mass loss temperature. $[4,46,68]$ In the first case, $\mathrm{T}_{\text {onset }}$ is determined by the intersection of two lines, by using a software or manually. The first one is a straight baseline along the temperature axis (in the low-temperature region with no weight-loss), and the second is the tangent of the mass $v s$ temperature curve as decomposition occurs (in the high-temperature region).[24, 36, 47, 57] The reliability of the onset temperature is estimated at $5{ }^{\circ} \mathrm{C}$ from determining the tangents.[36, 44, 46, 69, 70]

In the literature, the disparity between these different definitions is well stated and it is admitted that thermal degradation occurs well before the $\mathrm{T}_{\text {onset }}$ based on tangents method.[46, $62,64,71]$ The definitions and the corresponding values for start, onset and peak temperatures in the case of $\left[\mathrm{C}_{1} \mathrm{C}_{4} \mathrm{Im}\right]\left[\mathrm{NTf}_{2}\right]$ are illustrated in Figure 2. 


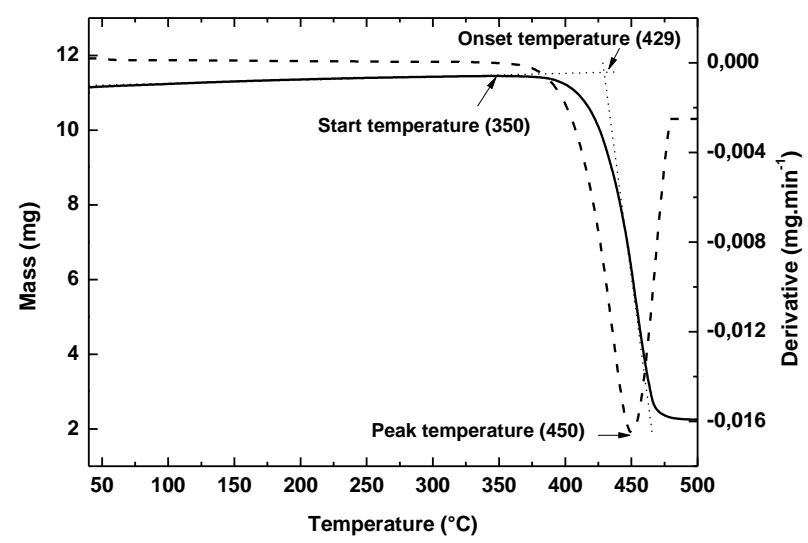

Figure 2. Comparison of the $\mathrm{T}_{\mathrm{d}}$ values of $\left[\mathrm{C}_{1} \mathrm{C}_{4} \mathrm{Im}\right]\left[\mathrm{NTf}_{2}\right]$ $\left(5^{\circ} \mathrm{C} \cdot \mathrm{min}^{-1}\right.$, argon flow) according to the definitions $\mathrm{T}_{\text {onset }}$, $\mathrm{T}_{\text {start }}$ and $\mathrm{T}_{\text {peak }}$; full line represents the sample mass and dashed line represents the first derivative

\subsection{Heat rate}

In TGA experiments the heat rate can vary from 1 to $20^{\circ} \mathrm{C} \cdot \mathrm{min}^{-1} .[22,35,61,72]$ For very slow rates the observed degradation can overlap long term degradation processes. Contrarily, high heat rates lead to an overestimation of $\mathrm{T}_{\mathrm{d}}$. This explains the difference of $c a 50{ }^{\circ} \mathrm{C}$ between $\mathrm{T}_{\text {onset }}$ of $\left[\mathrm{C}_{1} \mathrm{C}_{4} \operatorname{Im}\right]\left[\mathrm{NTf}_{2}\right]$ at different heat rates, being equal to $418{ }^{\circ} \mathrm{C}$ at a heating rate of $2{ }^{\circ} \mathrm{C} \cdot \mathrm{min}^{-1}$, while it is 427,443 and $473{ }^{\circ} \mathrm{C}$ at heating rates of 5,10 and $20{ }^{\circ} \mathrm{C} \cdot \mathrm{min}^{-1}$, respectively. The trend is also observed for $\left[\mathrm{C}_{1} \mathrm{C}_{1} \mathrm{C}_{4} \mathrm{Im}\right]\left[\mathrm{BF}_{4}\right]$ or $\left[\mathrm{C}_{1} \mathrm{C}_{2} \mathrm{Im}\right]\left[\mathrm{NTf}_{2}\right]$ IL.[3, 46, 53] We choose a rate of $5{ }^{\circ} \mathrm{C}$ to provide a good estimation of the $\mathrm{T}_{\text {start }}$ in reasonable experimental times.

\subsection{Pan nature}

Several pan materials like aluminum, $[24,66,75$, 76] platinum,[22, 36, 46, 72, 74, 77, 78] and ceramic $[4,24,48]$ can be used to run TGA experiments. They can be sealed (in the case of aluminum) or open. The difference between alumina and aluminum pans is minor (less than $5{ }^{\circ} \mathrm{C}$ ) for almost all the IL.[22] But in some specific cases, $\mathrm{NTf}_{2}$ anions induce corrosion of aluminum collectors used for Li-ion batteries.[77, 78] We choose to use aluminum pans easily prepared and sealed in an argon-filled glovebox.

\subsection{Atmosphere}

A large variety of gases can be used such as nitrogen,[20, 22, 25, 27, 35, 36, 44, 63, 64, 66, 69, 73, 79-83], argon,[26, 67, 75, 76, 84, 85], helium,[34] and air.[37, 61, 86, 87] Employing different inert gases such as $\mathrm{Ar}$ or $\mathrm{N}_{2}$ induces a slight change on the $\mathrm{T}_{\mathrm{d}}$ values, $[32,65,72]$ while air or oxygen lowers the $\mathrm{T}_{\mathrm{d}}[32,61,88]$ The TGA experiments are carried out under argon, and the gas flow is set to $30 \mathrm{~mL} \cdot \mathrm{min}^{-1}$.

\subsection{Sample mass}

The mass of the sample for TGA experiments is reported from 5 to $40 \mathrm{mg}$, typically corresponding to one drop of ionic liquid.[34, 46, 69, 73-75, 83, 85] For a same product e.g. $\left[\mathrm{C}_{1} \mathrm{C}_{4} \operatorname{Im}\right]\left[\mathrm{BF}_{4}\right]$, TGA performed on a 13 or $30 \mathrm{mg}$ sample can lead to a $\mathrm{T}_{\mathrm{d}}$ difference of up to $50{ }^{\circ} \mathrm{C}$ (at $10^{\circ} \mathrm{C} \cdot \mathrm{min}^{-1}$ under air).[61] This change may be due at least in part to the instrument type, specifically to the position of the thermocouple relatively to the sample.[61] To improve the heat diffusion through the sample and to avoid uneven heating,[74] low mass samples are preferred. The $\mathrm{T}_{\mathrm{d}}$ modification is not significantly observed on 
$\left[\mathrm{C}_{1} \mathrm{C}_{4} \mathrm{Im}\right]\left[\mathrm{NTf}_{2}\right]\left(>2{ }^{\circ} \mathrm{C}\right)$ with our protocol, most probably due to the lower heat rate. In all our experiments the sample mass is set to $10 \pm 3 \mathrm{mg}$.

\subsection{Purity}

Traces of impurities such as residual starting materials or salts $\left(\mathrm{Li}^{+}, \mathrm{Na}^{+}\right)$strongly affect $\mathrm{T}_{\mathrm{d} .}$ [89-91] Less than $1 \mathrm{w} \%$ of water do not alter $\mathrm{T}_{\mathrm{d}},[46,72]$ while even with highly hydrophobic IL higher water concentrations deeply lower $\mathrm{T}_{\mathrm{d}}$, e.g. of $45^{\circ} \mathrm{C}$ for $\left[\mathrm{C}_{1} \mathrm{C}_{4} \mathrm{Im}\right]\left[\mathrm{NTf}_{2}\right]$.[39] In order to remove water, IL are stirred and heated under high vacuum for one or two days, affording a water amount varying from 1 to $2000 \mathrm{ppm}$, Table 4.

\begin{tabular}{cccc}
\hline $\begin{array}{c}\text { Drying conditions } \\
\text { Temperature } \\
\left({ }^{\circ} \mathbf{C}\right)\end{array}$ & $\begin{array}{c}\text { Duration } \\
(\mathbf{h})\end{array}$ & $\begin{array}{c}\text { Pressure } \\
(\mathbf{m b a r})\end{array}$ & $\begin{array}{c}\text { Water } \\
\text { content } \\
(\mathbf{p p m})\end{array}$ \\
\hline 60 then 120 & 2 then 20 & n.a. & $<1[92]$ \\
80 then 120 & 12 then 24 & $10^{-5}$ & $<10[93]$ \\
120 & $<48$ & n.a. & $<17.5[76]$ \\
100 & n.a. & n.a. & $<20[22]$ \\
65 & 48 & n.a. & $<20[89]$ \\
80 & 48 & $10^{-3}$ & $<50[94]$ \\
100 & 24 & n.a. & $<50[95,96]$ \\
25 & 48 & $10^{-5}$ & $<60$, this \\
& & & work \\
60 & overnight & n.a. & $1000[97]$ \\
70 & 12 & n.a. & $<2000[85]$ \\
60 & 48 & 1 & n.a. $[69,70]$ \\
\hline
\end{tabular}

Table 4. Influence of the drying duration, pressure and temperature on the IL water content; n.a.: not available

\subsection{Selected experimental parameters}

From the above results, all our results presented in the following part are compared under identical conditions. The TGA samples containing $10 \pm 3 \mathrm{mg}$ of purified and dried IL are prepared in aluminum sealed pans in an argon- filled glovebox, and the measurements are performed at $5^{\circ} \mathrm{C} \cdot \mathrm{min}^{-1}$ under argon. The start decomposition temperature is defined as the temperature at which $|\mathrm{dw} / \mathrm{dT}|>10^{-4} \mathrm{mg} \cdot \mathrm{s}^{-1}$.

\section{Playing around imidazolium cation}

\subsection{Mechanisms of Im-IL decomposition}

Imidazolium-based IL degradation occur through different mechanisms, the main one being the loss of alkyl chains.[49, 53, 57, 98, 101] For example the nucleophilic substitution $\left(S_{N} 2\right)$ of the alkyl group by the anion (reverse Menschutkin reaction) is reported,[21, 32, 35, 49, 52, 55-57, 100-102] as well as Hofmann elimination yielding alkenes from the break of the N-C bond, Figure 3.[21, 37, 64, 98, 101] The terminal alkene is formed, and different isomers of the alkenes can be obtained after rearrangements.[32, 103-105] Also $\mathrm{N}$-heterocyclic carbene (NHC) at the $\mathrm{C}_{2}$ position can be formed due to the presence of an acidic proton, Figure 4.[32, 103-105] The opening of the cation ring occurs at much higher temperatures.[32, 106]

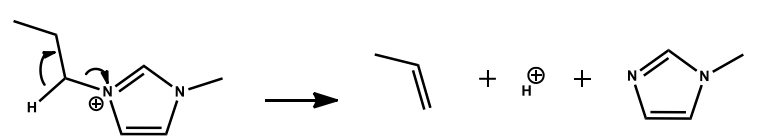

Figure 3. Hofmann elimination [37, 64, 98, 101]

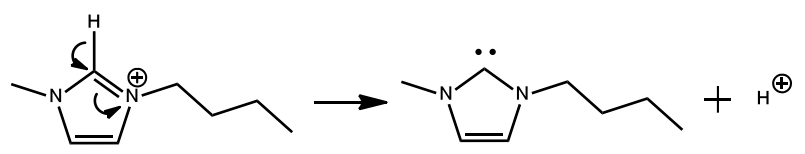

Figure 4. Formation of N-heterocyclic carbene NHC [32, 103-105] 


\subsection{Alkyl chain effects}

The impact of the nature of the alkyl chain is studied varying their length and their substitution by alkyl chains, heteroatoms or unsatured groups.

\subsubsection{Alkyl chain length}

The $\mathrm{T}_{\text {onset }}$ and $\mathrm{T}_{\text {start }}$ evolutions of $\left[\mathrm{C}_{1} \mathrm{C}_{\mathrm{n}} \mathrm{Im}\right]\left[\mathrm{NTf}_{2}\right]$ in function of $n$ (number of carbon atoms varying from 2 to 18) are depicted in Figure 5.

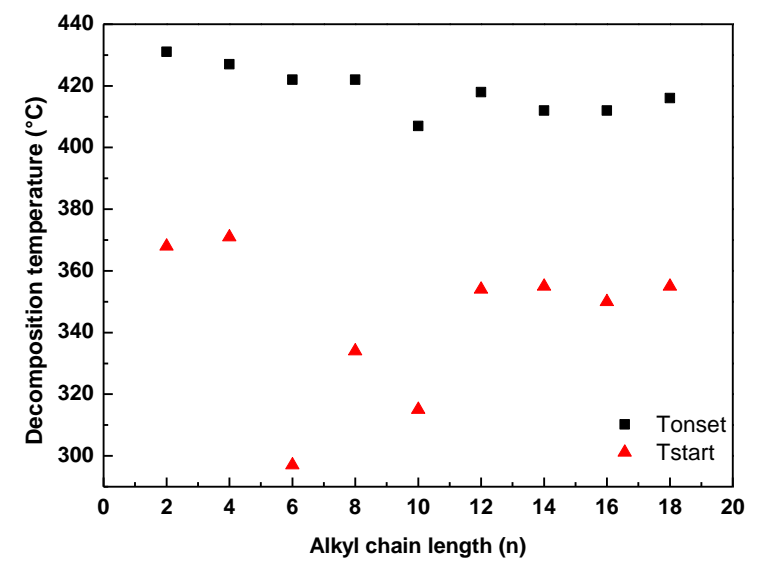

Figure 5. Influence of the alkyl chain length on the $\mathrm{T}_{\text {onset }}$ and $\mathrm{T}_{\text {start }}$ for $\left[\mathrm{C}_{1} \mathrm{C}_{\mathrm{n}} \mathrm{Im}\right]\left[\mathrm{NTf}_{2}\right]$

For these alkyl systems, in addition to H-bond network between anions and cations, simulation and experimental results report side-chain aggregation when $n>4$, but no aggregation for shorter chains. These systems form of a continuous tridimensional network of ionic channels, coexisting with nonpolar domains.[107, 108] The size of these nonpolar domains is found linear with the alkyl chain length $(\sim 2.1 \AA)$, and Van des Waals interactions between these alkyl chains increase of $\sim 4.7$ kJ.mol ${ }^{-1}$ per $\mathrm{CH}_{2}$ group.[109]

From $\left[\mathrm{C}_{1} \mathrm{C}_{1} \mathrm{Im}\right]$ to $\left[\mathrm{C}_{1} \mathrm{C}_{4} \mathrm{Im}\right]$, the decomposition temperature $\left(\mathrm{T}_{\mathrm{d}}\right)$ decreases with the molecular mass of the IL.[3, 20, 25, 28, 32, 102] For these short alkyl chains (i.e. with a $\mathrm{C}_{\mathrm{n}}$ length $\sim 4 \AA$ ), the charge-rich region is localised on imidazolium ring and the probability of alkyl chain segregation is weak.[107, 108, 110] These IL are mainly structured through electrostatic and hydrogen-bond interactions, leading to the formation of charge ordering over two or three coordination shells.[108]

When $n$ increases from 4 to 6 carbons (i.e. length $\left.\mathrm{C}_{\mathrm{n}} \sim 5.5 \AA\right), \mathrm{T}_{\text {start }}$ decreases sharply, resulting from two factors. First, when $n$ increases a breakdown in the symmetry of imidazolium ring is observed. Secondly, the longer alkyl chains constitute better leaving groups (more stable carbocations and carbon radicals).[102] Note that $\mathrm{T}_{\mathrm{d}}$ as others physical constants e.g. heat capacity display a similar trend shift with $\left[\mathrm{C}_{1} \mathrm{C}_{6} \operatorname{Im}\right]\left[\mathrm{NTf}_{2}\right] .[107,111-113]$

For $\left[\mathrm{C}_{1} \mathrm{C}_{\mathrm{n}} \mathrm{Im}\right]$ containing longer alkyl chains $(n>6), T_{d}$ increases though the longer alkyl chains are better leaving groups,[45] in particular with $n$ varying from 10 to 18 (length $\mathrm{C}_{\mathrm{n}} \sim 12 \AA$ ). This result may be related to higher van der Waals interactions with long alkyl-chains.[40, 107-109, 114]

\subsubsection{Asymmetric $\left[\mathrm{C}_{1} \mathrm{C}_{2 n} \mathrm{Im}\right]\left[\mathrm{NTf}_{2}\right]$ vs symmetric $\left[\mathrm{C}_{\mathrm{n}} \mathrm{C}_{\mathrm{n}} \mathrm{Im}\right]\left[\mathrm{NTf}_{2}\right]$}

The symmetric dialkylsubstituted imidazolium such as $\left[\mathrm{C}_{6} \mathrm{C}_{6} \mathrm{Im}\right]\left[\mathrm{NTf}_{2}\right]$ decomposes at higher temperature than $\left[\mathrm{C}_{4} \mathrm{C}_{4} \mathrm{Im}\right]\left[\mathrm{NTf}_{2}\right]$, from a larger carbon number as observed with asymmetric substituted IL (vide supra). Nevertheless 
$\left[\mathrm{C}_{4} \mathrm{C}_{4} \operatorname{Im}\right]\left[\mathrm{NTf}_{2}\right]$ and $\left[\mathrm{C}_{6} \mathrm{C}_{6} \operatorname{Im}\right]\left[\mathrm{NTf}_{2}\right]$ have lower $T_{d}$ than their asymmetric IL counterparts, with a comparable total number of carbons in the alkyl chains, $\left[\mathrm{C}_{1} \mathrm{C}_{8} \operatorname{Im}\right]\left[\mathrm{NTf}_{2}\right]$ and $\left[\mathrm{C}_{1} \mathrm{C}_{12} \mathrm{Im}\right]\left[\mathrm{NTf}_{2}\right]$ respectively, Figure 6.

Likewise, the volatility of $\left[\mathrm{C}_{n} \mathrm{C}_{n} \operatorname{Im}\right]\left[\mathrm{NTf}_{2}\right]$ IL is significantly higher than for $\left[\mathrm{C}_{1} \mathrm{C}_{2 \mathrm{n}} \mathrm{Im}\right]\left[\mathrm{NTf}_{2}\right]$ counterparts.[111] This observation is attributed, from the small- and wide- angle X-ray scattering (SWAXS) measurements, to the steric hindrance stemming from the symmetric chains connected to the cations which tend to separate the stacked imidazolium rings more than in the case of asymmetric cations.[111] This steric hindrance can confirm a lower $\mathrm{T}_{\mathrm{d}}$ of $\left[\mathrm{C}_{\mathrm{n}} \mathrm{C}_{\mathrm{n}} \operatorname{Im}\right]\left[\mathrm{NTf}_{2}\right]$ as compared to $\left[\mathrm{C}_{1} \mathrm{C}_{2 n} \mathrm{Im}\right]\left[\mathrm{NTf}_{2}\right]$, Figure 6 .

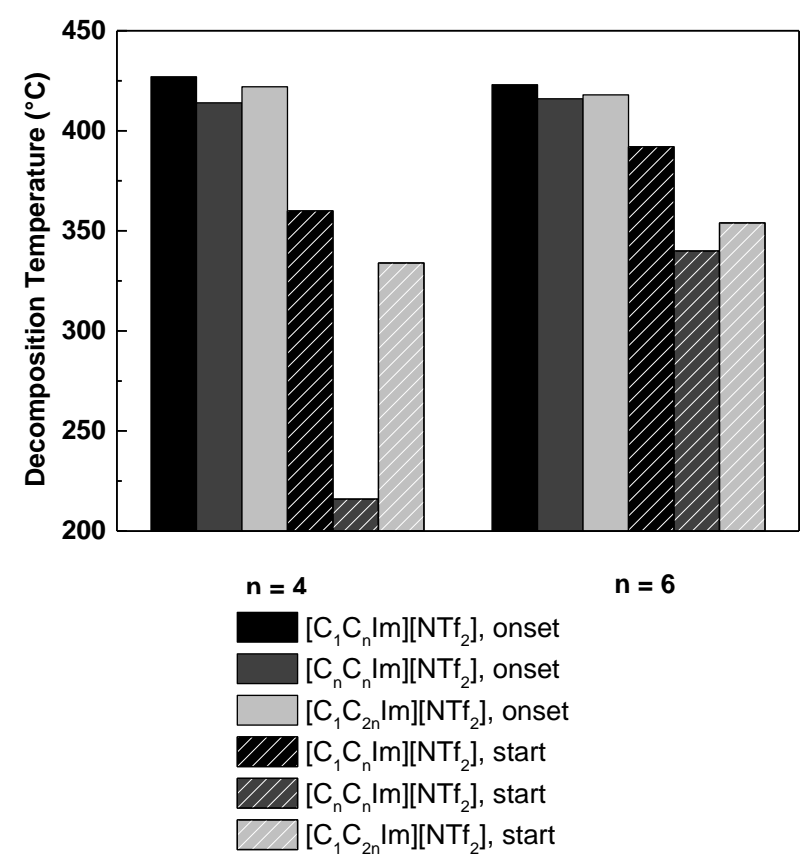

Figure 6. Effect of the symmetry of alkyl chains on $T_{d}$ of several $[\mathrm{Im}]\left[\mathrm{NTf}_{2}\right]$-based IL

\subsubsection{Linear $v s$ branched alkyl chains}

The $\left[\mathrm{C}_{1} \mathrm{C}_{3} \operatorname{Im}\right]\left[\mathrm{NTf}_{2}\right]$ IL with branched alkyl chains shows a lower $T_{d}$ than the linear analogous (453 vs $\left.409{ }^{\circ} \mathrm{C}\right) .[22]$ Indeed, the branched alkyl chains increases the cation volume, inducing a higher disorder in the structure, separating the stacked imidazolium rings and lowering intramolecular electrostatic interactions. Moreover, branched alkyl chains are better leaving groups, affording more stable carbocations and carbon radicals, favoring the decomposition reaction (vide supra).[32, 35]

\subsection{4. $\mathrm{C}_{2}-\mathrm{H}$ substitution}

No obvious $T_{d}$ difference is observed between $\left[\mathrm{C}_{1} \mathrm{C}_{\mathrm{n}} \mathrm{Im}\right]\left[\mathrm{NTf}_{2}\right]$ and $\left[\mathrm{C}_{1} \mathrm{C}_{1} \mathrm{C}_{\mathrm{n}} \mathrm{Im}\right]\left[\mathrm{NTf}_{2}\right]$ (1-alkyl2,3-dimethylimidazolium), with $n=4$ and 6.[4, $22,32]$ The substitution of the other acidic protons to form $\left[\mathrm{C}_{1} \mathrm{C}_{1} \mathrm{C}_{1} \mathrm{C}_{1} \mathrm{C}_{1} \mathrm{Im}\right]$ (5 methyl groups on imidazolium ring) leads to minor increase of the $T_{d}$.[47] However, the potential formation of NHC, Figure 4, limits their thermal stability with time and in the presence of any basic substrate, Figure 7.[7, 115-117]

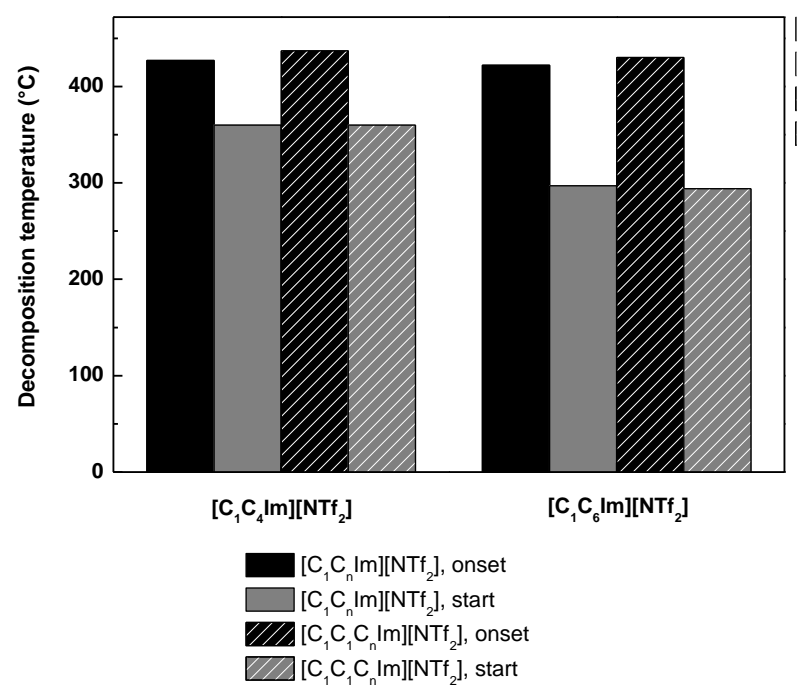

Figure 7. Effect of the $\mathrm{C}_{2}-\mathrm{H}$ substitution of imidazoliumbased IL on their $\mathrm{T}_{\mathrm{d}}$; this work 


\subsubsection{Alkyl chain functionalization}

\subsubsection{Fluoroalkyl $v s$ alkyl chains}

The fluorinated chains induce a $T_{d}$ decrease compared to the alkyl analogous, Table 5. This can be explained by higher repulsion between fluoroalkyl chains, since the magnitude of the C$\mathrm{F}$ bond dipole moment is $1.4 \mathrm{D}$ vs $0.4 \mathrm{D}$ for C-H bonds.[118, 119] This intermolecular repulsion tends to separate the stacked imidazolium rings, and contributes to a higher volatility of fluoroalkanes vs alkanes, and lower $\mathrm{T}_{\mathrm{d}}$ values.[119-121]

\begin{tabular}{cc}
\hline Ionic liquid & $\begin{array}{c}\mathbf{T}_{\text {onset }} \\
\left({ }^{\circ} \mathbf{C}\right)\end{array}$ \\
\hline 1,3-dibutylimidazolium $\left[\mathrm{C}_{4} \mathrm{C}_{4} \mathrm{Im}\right]$ & 414 \\
1-(3,3,4,4,4-pentafluorobutyl)-3-butyl & 390 \\
imidazolium $\left[\mathrm{C}_{4} \mathrm{C}_{4 \mathrm{f}} \mathrm{Im}\right]$ & \\
1,3-dihexylimidazolium $\left[\mathrm{C}_{6} \mathrm{C}_{6} \mathrm{Im}\right]$ & 416 \\
1-(3,3,4,4,5,5,6,6,6-nonafluorohexyl)-3- & 390 \\
hexylimidazolium [ $\left.\mathrm{C}_{6} \mathrm{C}_{6} \mathrm{Im}\right]$ & \\
\hline
\end{tabular}

Table 5. Effect of the fluorination of alkyl chains of imidazolium-based IL on their $\mathrm{T}_{\mathrm{d}}$, this work

\subsubsection{Unsaturations}

IL containing unsaturated chains are generally less stable than their saturated counterparts, Figure 8. Adding a second unsaturation generally lowers even more the stability,[26, 122] except for benzyl $\left(\mathrm{CH}_{2}-\mathrm{Ph}\right)$-derived $\mathrm{IL}$ due to the aromaticity and $\pi$-stacking of the $\mathrm{C}_{6} \mathrm{H}_{5}$ cycle. [45] The $T_{d}$ of alkyne-functionalised IL is lower than the alkene-functionalised IL, e.g. $\mathrm{T}_{\mathrm{d}}$ of 1-allyl3-methylimidazolium bromide is $253{ }^{\circ} \mathrm{C}$ vs $192{ }^{\circ} \mathrm{C}$ for 1-propargyl-3-methylimidazolium bromide. The $\mathrm{T}_{\mathrm{d}}$ lowering can be related to the presence of an $\mathrm{H}$-bond $\left(\mathrm{Br} \cdot \cdot \mathrm{H}-\mathrm{C}_{\text {acetylene }}\right)$ in the propargyl one, reducing the strength of the
$\mathrm{H}$-bonds between anion and the $\mathrm{C}_{2}-\mathrm{H}$ of the cation and consequently the interconnection of the 3D-structure of IL.[123, 124]

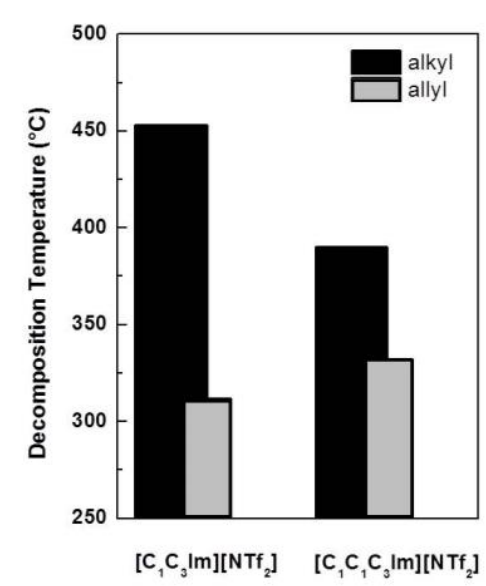

Figure 8. Effect of the presence of allyl group on different types of IL; $\left[\mathrm{C}_{1} \mathrm{C}_{3} \operatorname{Im}\right]\left[\mathrm{NTf}_{2}\right]$, this work; $\left[\mathrm{C}_{1} \mathrm{C}_{1} \mathrm{C}_{3} \mathrm{Im}\right]\left[\mathrm{NTf}_{2}\right]$, $[32,67]$

\subsubsection{Functionalised IL}

The $T_{d}$ of a series of imidazolium-IL with alkyl chain length functionalised with cyano, ether or hydroxyl groups are reported in Figure 9 and Table 6.

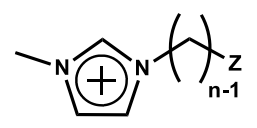

Figure 9. Functionalised imidazolium IL where $\mathrm{Z}$ can be $\mathrm{OH}, \mathrm{CN}$ or $\mathrm{CH}_{3}$ group

\begin{tabular}{cccc}
\hline $\begin{array}{c}\mathbf{T}_{\text {start }} \\
\left({ }^{\circ} \mathbf{C}\right)\end{array}$ & Alkyl & Cyano & Alcohol \\
\hline $\mathrm{n}=2$ & $368^{\mathrm{a}}$ & $303^{\mathrm{a}}$ & $368^{\mathrm{a}}$ \\
$\mathrm{n}=4$ & $371^{\mathrm{a}}$ & $361^{\mathrm{a}}$ & \\
$\mathrm{n}=6$ & $297^{\mathrm{a}}$ & $373^{\mathrm{a}}$ & $318^{\mathrm{a}}$ \\
\hline
\end{tabular}

Table 6. Influence of the functional groups on the $T_{\text {start }}$ of [NTf 2$]-I L ; ~{ }^{a}$ this work

For short alkyl chains, i.e. $\mathrm{n} \leq 4$, the thermal stability is lowered by the addition of functional groups. For example changing from $\left[\mathrm{C}_{1}\left(\mathrm{CH}_{2} \mathrm{CH}_{3}\right) \mathrm{Im}\right]$ to $\left[\mathrm{C}_{1}\left(\mathrm{CH}_{2} \mathrm{CN}\right) \mathrm{Im}\right]$ cation decreases the $\mathrm{T}_{\text {onset }}$ from $278^{\circ} \mathrm{C}[21]$ to 
$251{ }^{\circ} \mathrm{C}[125]\left(\Delta=-27{ }^{\circ} \mathrm{C}\right)$ when associated to chloride anion, from $275^{\circ} \mathrm{C}[56]$ to $210^{\circ} \mathrm{C}[22]$ $\left(\Delta=-65^{\circ} \mathrm{C}\right)$ with $\left[\mathrm{N}(\mathrm{CN})_{2}\right]$ anion, and from $431{ }^{\circ} \mathrm{C}$ to $406{ }^{\circ} \mathrm{C}$ with $\left[\mathrm{NTf}_{2}\right]$ anion, this work. The same tendency is detected with hydroxyl- and ether-functionalised IL, $e \cdot g$.

$\left[\mathrm{C}_{1} \mathrm{C}_{1}\left(\left(\mathrm{CH}_{2}\right)_{2} \mathrm{O}\left(\mathrm{CH}_{2}\right)_{2}\right) \operatorname{Im}\right]\left[\mathrm{NTf}_{2}\right]$ decomposes at $405{ }^{\circ} \mathrm{C}$ while the $\mathrm{T}_{\mathrm{d}}$ of $\left[\mathrm{C}_{1} \mathrm{C}_{1} \mathrm{C}_{4} \operatorname{Im}\right]\left[\mathrm{NTf}_{2}\right]$, is $430{ }^{\circ} \mathrm{C} .[126]$ Adding other alkoxy groups in the chain lowers $\mathrm{T}_{\mathrm{d}}$, Figure 10.[2, 34, 66, 126-130]
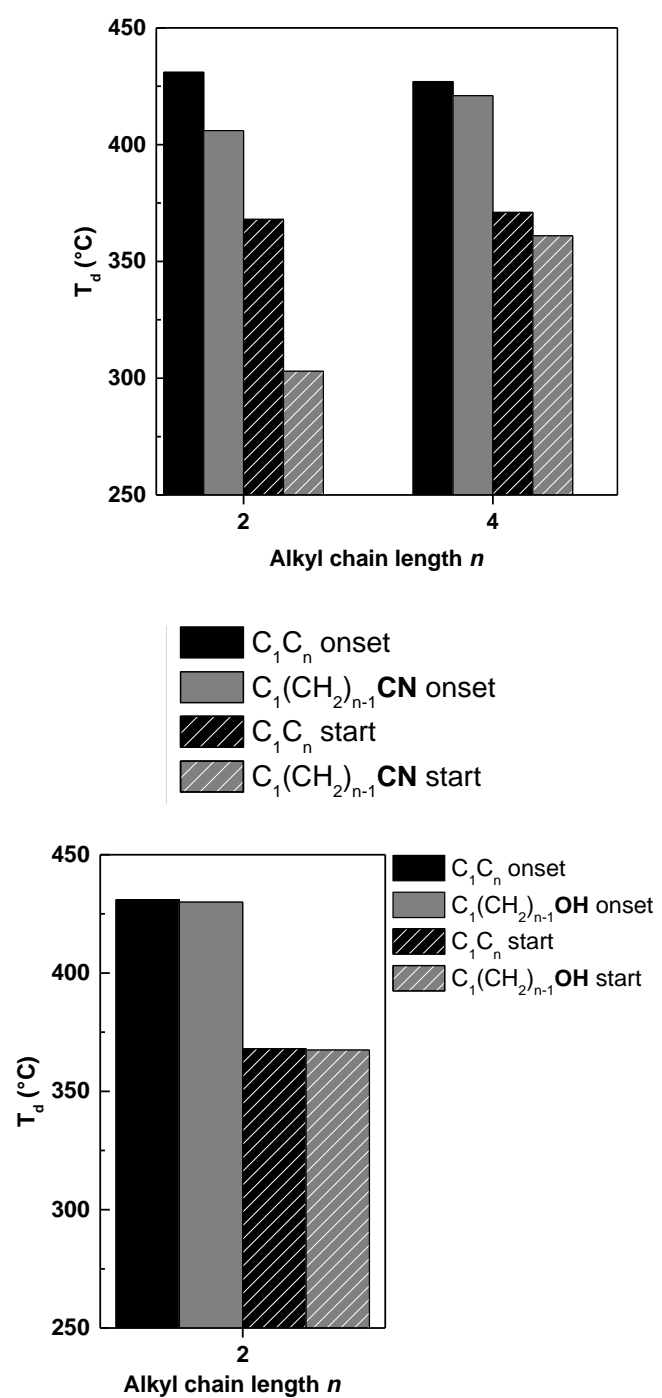

Figure 10. Influence of the presence of a cyano (left) or hydroxyl (right) group on $T_{d}$ for short alkyl chains $(n \leq 4)$

The negative effect of the presence of a function on $\mathrm{T}_{\mathrm{d}}$ can be explained by the formation of $\mathrm{H}^{-}$ bonds between functional moieties $(\mathrm{C} \equiv \mathrm{N}$ or $\mathrm{O})$ and the $\mathrm{C}_{2}-\mathrm{H}$ proton of imidazolium ring. These $\mathrm{H}$-bonds (enthalpy value of $3.4 \mathrm{kcal} . \mathrm{mol}^{-1}$ ) are evidenced through $\mathrm{X}$-ray diffraction, Infrared and Raman spectroscopies, and density functional theory in IL based on [ $\left.\mathrm{C}_{1}\left(\mathrm{CH}_{2} \mathrm{CH}_{2} \mathrm{OH}\right) \mathrm{Im}\right]$ and $\left[\left(\mathrm{CH}_{2} \mathrm{CH}_{2} \mathrm{OH}\right)_{2} \mathrm{Im}\right] .[131]$ These interactions reduce the strength of the $\mathrm{H}$-bonds between [NTf $\left.{ }_{2}\right]$ and the $\mathrm{C}_{2}-\mathrm{H}$, inducing lower $\mathrm{T}_{\mathrm{d}}$ for IL containing functional groups $\left(\left[\mathrm{C}_{1} \mathrm{C}_{2} \operatorname{Im}\right]\left[\mathrm{NTf}_{2}\right]\right.$ decomposes at $431{ }^{\circ} \mathrm{C}$, this work, vs $395{ }^{\circ} \mathrm{C}$ for $\left.\left[\left(\mathrm{CH}_{2} \mathrm{CH}_{2} \mathrm{OH}\right)_{2} \mathrm{Im}\right]\left[\mathrm{NTf}_{2}\right]\right) \cdot[68]$.

At the opposite, for the longer chains, higher $\mathrm{T}_{\text {start }}$ are observed for the functionalised chains (cyano and hydroxyl) compared to alkyl analogues $\mathrm{T}_{\mathrm{d}}$ increases from $422{ }^{\circ} \mathrm{C}$ for $\left[\mathrm{C}_{1} \mathrm{C}_{6} \mathrm{Im}\right]\left[\mathrm{NTf}_{2}\right]$ to $428{ }^{\circ} \mathrm{C}$ for $\left[\mathrm{C}_{1}\left(\left(\mathrm{CH}_{2}\right)_{5} \mathrm{CN}\right) \operatorname{Im}\right]\left[\mathrm{NTf}_{2}\right]$, Figure 11.
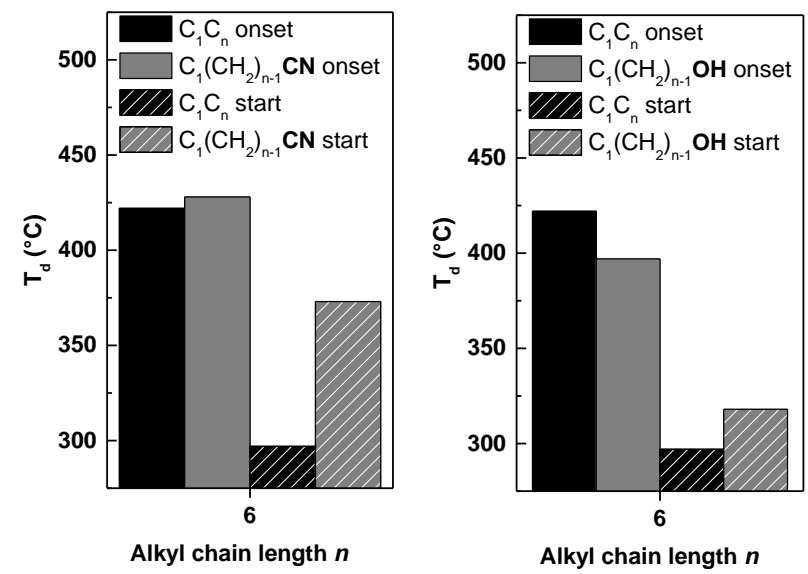

Figure 11. Influence of the presence of a cyano or hydroxyl group on $\mathrm{T}_{\mathrm{d}}$ for long alkyl chains, this work

This trend can be explained by enhanced Van der Waals intermolecular interactions in longer chains. Furthermore with ether-based IL, a stronger interaction between the cations and the 
lone electron pairs of oxygen atoms can induce a wrapping of the chain around the cation protecting the imidazolium ring from nucleophilic attacks, leading to higher stability.[132, 133]

\section{Conclusions}

The objective of this work is to determine the factors influencing thermal stability of imidazolium-based ionic liquids associated to bis(trifluoromethanesulfonyl)imide anion [NTf $\mathrm{NT}_{2}$. Their decomposition occurs via nucleophilic substitution, Hofmann elimination or NHC formation. For these postulated mechanisms, both the natures of the anion and of the side chains of the cation have a crucial impact. From a perusal of the literature data and from our results, we postulate that the thermal stability of these IL is mostly controlled by structural and kinetic factors.

IL thermal stability is ruled by intermolecular interactions. The three most important ones are H-bonds, occurring between hydrogen and heteroatoms from anion or functionalised cation, coulombic interactions between anionic and cationic charges, and Van der Waals interactions between the side chains of the imidazolium rings. When the substitution of the alkyl chain induces a higher molecular volume of the cation, or the presence of Fluor atom, the $T_{d}$ decreases. High $\mathrm{T}_{\mathrm{d}}$ are induced by strong coulombic or van der Waals interactions, strong $\mathrm{H}$-bond between anion and $\mathrm{C}_{2} \mathrm{H}$, or by high symmetry. The more stable
IL are thus constituted of linear and short alkyl chains, with no functional groups, i.e. $\left[\mathrm{C}_{1} \mathrm{C}_{2} \mathrm{Im}\right]$.

\section{Experimental part}

The ionic liquids are synthesised and characterised after purification as already reported in the literature.[7, 31, 134] Before TGA analyses, all IL are vacuum-dried at room temperature for $48 \mathrm{~h}$ under high vacuum $\left(10^{-5} \mathrm{mbars}\right)$ and stored in an argon-filled glovebox. Their impurity levels are then measured. Their water content is lower than 60 ppm (mass ratio), as assessed by Karl Fisher coulometric titration, 831 Coulometer Metrohm. The chloride content is lower than $0.5 \%$ as assessed by high resolution mass spectroscopy, close to $100 \mathrm{ppm}$ as measured by elementary analysis. Thermal characterisations are performed with a Mettler Toledo TGA/DSC1 thermobalance equipped with an auto-sampler and a DSC heat flow measurement for simultaneous detection of enthalpy events. Indium and aluminium are used for the temperature calibration.

\section{Acknowledgements}

C.C.S. would like to thank Pr T. Welton for fruitful discussion.

\section{References}

[1] P. Wasserscheid and T. Welton, eds., Ionic liquids in synthesis, Wiley-VCH, Weinheim, 2008

[2] Z. B. Zhou, H. Matsumoto and K. Tatsumi, Chem. Eur. J., 2005, 11, 2

[3] M. Villanueva, A. Coronas, J. Garcia and J. Salgado, Ind. Eng. Chem. Res., 2013, 52, 45 
[4] D. M. Fox, W. H. Awad, J. W. Gilman, P. H. Maupin, H. C. De Long and P. C. Trulove, Green Chem., 2003, 5, 6

[5] D. M. Fox, J. W. Gilman, A. B. Morgan, J. R. Shields, P. H. Maupin, R. E. Lyon, H. C. De Long and P. C. Trulove, Ind. Eng. Chem. Res., 2008, 47, 16

[6] A. O. Diallo, C. Len, A. B. Morgan and G. Marlair, Sep. Purif. Technol., 2012, 101

[7] L. Chancelier, A. O. Diallo, C. C. Santini, G. Marlair, T. Gutel, S. Mailley and C. Len, Phys. Chem. Chem. Phys., 2014, 16, 5

[8] Y. D. Hu, P. Xu, H. G. Gui, X. X. Wang and Y. S. Ding, Composites Part A, 2015, 77

[9] T. Welton, Chem. Rev., 1999, 99, 8

[10] S. Werner, M. Haumann and P. Wasserscheid, Annu. Rev. Chem. Biomol. Eng., 2010, 1

[11] X. J. Yang, R. S. Yang, D. Q. Shi, S. X. Wang, J. Chen and H. Guo, J. Chem. Technol. Biotechnol., 2015, 90, 6

[12] H. Olivier-Bourbigou, L. Magna and D. Morvan, Appl. Catal., A, 2010, 373, 1-2

[13] L. Crowhurst, N. L. Lancaster, J. M. PerezArlandis and T. Welton, J. Am. Chem. Soc., 2004, 126,37

[14] H.-P. Steinrueck and P. Wasserscheid, Catal. Lett., 2015, 145, 1

[15] K. Staerk, N. Taccardi, A. Boesmann and P. Wasserscheid, Chem. Sus. Chem, 2010, 3, 6

[16] F. Guo, S. J. Zhang, J. J. Wang, B. T. Teng, T. Y. Zhang and M. H. Fan, Curr. Org. Chem., 2015, 19,5

[17] M. Armand, F. Endres, D. R. MacFarlane, H. Ohno and B. Scrosati, Nat. Mater., 2009, 8, 8

[18] H. Nakagawa, Electrochemistry, 2015, 83, 9

[19] G. B. Appetecchi, M. Montanino and S. Passerini, in Ionic Liquids: Science and Applications, ed. ACS, Washington, 2012

[20] H. Tokuda, K. Hayamizu, K. Ishii, M. Susan and M. Watanabe, J. Phys. Chem. B, 2005, 109, 13

[21] N. Meine, F. Benedito and R. Rinaldi, Green Chem., 2010, 12, 10

[22] H. L. Ngo, K. LeCompte, L. Hargens and A. B. McEwen, Thermochim. Acta, 2000, 357

[23] M. L. Mutch and J. S. Wilkes, Proceedings of the 11th International Symposium on Molten Salts, 1998, 98-11

[24] M. E. Van Valkenburg, R. L. Vaughn, M. Williams and J. S. Wilkes, Thermochim. Acta, 2005, 425,1

[25] T. Nishida, Y. Tashiro and M. Yamamoto, $J$. Fluorine Chem., 2003, 120, 2

[26] G.-H. Min, T. Yim, H. Y. Lee, D. H. Huh, E. Lee, J. Mun, S. M. Oh and Y. G. Kim, Bull. Korean Chem. Soc., 2006, 27, 6

[27] A. B. McEwen, S. F. McDevitt and V. R. Koch, J. Electrochem. Soc., 1997, 144, 4

[28] S. Holopainen, M. Nousiainen, J. Puton, M. Sillanpaa, U. Bardi and A. Tolstogouzov, Talanta, 2011, 83, 3
[29] Y. X. An, P. J. Zuo, X. Q. Cheng, L. X. Liao and G. P. Yin, Int. J. Electrochem. Sc., 2011, 6, 7

[30] M. Ishikawa, T. Sugimoto, M. Kikuta, E. Ishiko and M. Kono, J. Power Sources, 2006, 162, 1

[31] P. Bonhote, A. P. Dias, N. Papageorgiou, K. Kalyanasundaram and M. Gratzel, Inorg. Chem., 1996, 35,5

[32] W. H. Awad, J. W. Gilman, M. Nyden, R. H. Harris, T. E. Sutto, J. Callahan, P. C. Trulove, H. C. DeLong and D. M. Fox, Thermochim. Acta, 2004, 409,1

[33] A. B. McEwen, H. L. Ngo, K. LeCompte and J. L. Goldman, J. Electrochem. Soc., 1999, 146, 5

[34] K. Liu, Y.-X. Zhou, H.-B. Han, S.-S. Zhou, W.-F. Feng, J. Nie, H. Li, X.-J. Huang, M. Armand and Z.-B. Zhou, Electrochim. Acta, 2010, 55, 23

[35] T. Erdmenger, J. Vitz, F. Wiesbrock and U. S. Schubert, J. Mater. Chem., 2008, 18, 43

[36] C. P. Fredlake, J. M. Crosthwaite, D. G. Hert, S. Aki and J. F. Brennecke, J. Chem. Eng. Data, 2004, 49,4

[37] O. E. Zhuravlev, N. V. Verolainen and L. I. Voronchikhina, Russ. J.Appl. Chem., 2011, 84, 7

[38] S. Kudo, Z. Zhou, K. Norinaga and J.-i. Hayashi, Green Chem., 2011, 13, 11

[39] J. G. Huddleston, A. E. Visser, W. M. Reichert, H. D. Willauer, G. A. Broker and R. D. Rogers, Green Chem., 2001, 3, 4

[40] J. D. Holbrey and K. R. Seddon, Dalton Trans., 1999, 13

[41] H. Tokuda, K. Hayamizu, K. Ishii, M. Abu Bin Hasan Susan and M. Watanabe, J. Phys. Chem. B, 2004, 108, 42

[42] L. Rodriguez-Perez, Y. Coppel, I. Favier, E. Teuma, P. Serp and M. Gomez, Dalton Trans., 2010, 39,32

[43] N. D. Harper, K. D. Nizio, A. D. Hendsbee, J. D. Masuda, K. N. Robertson, L. J. Murphy, M. B. Johnson, C. C. Pye and J. A. C. Clyburne, Ind. Eng. Chem. Res, 2011, 50, 5

[44] A. Muhammad, M. I. A. Mutalib, C. D. Wilfred, T. Murugesan and A. Shafeeq, J. Chem. Thermodyn., 2008, 40, 9

[45] P. S. Kulkarni, L. C. Branco, J. G. Crespo, M. C. Nunes, A. Raymundo and C. A. M. Afonso, Chem. Eur. J., 2007, 13, 30

[46] D. M. Fox, J. W. Gilman, H. C. De Long and P. C. Trulove, J. Chem. Thermodyn., 2005, 37, 9

[47] D. M. Blake, L. Moens, D. Rudnicki and H. Pilath, J. Sol. Energy Eng., 2006, 128, 1

[48] Y. Wang, K. Zaghib, A. Guerfi, F. F. C. Bazito, R. M. Torresi and J. R. Dahn, Electrochim. Acta, 2007, 52, 22

[49] M. T. Clough, K. Geyer, P. A. Hunt, J. Mertes and T. Welton, Phys. Chem. Chem. Phys., 2013, 15, 47

[50] Y. Cao and T. Mu, Ind. Eng. Chem. Res., 2014, 53, 8651

[51] E. M. Siedlecka, M. Czerwicka, S. Stolte and P. Stepnowski, Curr. Org. Chem., 2011, 15, 12 
[52] M. J. Earle, J. M. S. S. Esperanca, M. A. Gilea, J. N. C. Lopes, L. P. N. Rebelo, J. W. Magee, K. R. Seddon and J. A. Widegren, Nature, 2006, 439, 7078

[53] C. Maton, N. De Vos and C. V. Stevens, Chem. Soc. Rev., 2013, 42, 13

[54] M. Lee, Z. Niu, C. Slebodnick and H. W. Gibson, J. Phys. Chem. B, 2010, 114, 21

[55] A. G. Glenn and P. B. Jones, Tetrahedron Lett., 2004, 45, 37

[56] B. K. M. Chan, N.-H. Chang and M. R. Grimmett, Aust. J. Chem., 1977, 30, 9

[57] M. C. Kroon, W. Buijs, C. J. Peters and G.-J. Witkamp, Thermochim. Acta, 2007, 465, 1-2

[58] S. A. Forsyth, S. R. Batten, Q. Dai and D. R MacFarlane, Aust. J. Chem., 2004, 57, 2

[59] F. Heym, B. J. M. Etzold, C. Kern and A. Jess, Green Chem., 2011, 13, 6

[60] S. P. Verevkin, D. H. Zaitsau, V. N Emel'yanenko, A. V. Yermalayeu, C. Schick, H. Liu, E. J. Maginn, S. Bulut, I. Krossing and R. Kalb, J. Phys. Chem. B, 2013, 117, 21

[61] M. Kosmulski, J. Gustafsson and J. B. Rosenholm, Thermochim. Acta, 2004, 412, 1-2

[62] K. J. Baranyai, G. B. Deacon, D. R. MacFarlane, J. M. Pringle and J. L. Scott, Aust. J. Chem., 2004, 57,2

[63] R. E. Del Sesto, T. M. McCleskey, C. Macomber, K. C. Ott, A. T. Koppisch, G. A. Baker and A. K. Burrell, Thermochim. Acta, 2009, 491, 1-2

[64] T. J. Wooster, K. M. Johanson, K. J. Fraser, D. R. MacFarlane and J. L. Scott, Green Chem., 2006, 8,8

[65] Q. Zhou, W. A. Henderson, G. B. Appetecchi, M. Montanino and S. Passerini, J. Phys. Chem. B, 2008, 112, 43

[66] Z. J. Chen, S. M. Liu, Z. P. Li, Q. H. Zhang and Y. Q. Deng, New J. Chem., 2011, 35, 8

[67] T. Yim, H. Y. Lee, H.-J. Kim, J. Mun, S. Kim, S. M. Oh and Y. G. Kim, Bull. Korean Chem. Soc., 2007, 28, 9

[68] F. Deng, Z. K. Reeder and K. M. Miller, J. Phys. Org. Chem., 2014, 27, 1

[69] N. Papaiconomou, J. Salminen, J.-M. Lee and J. M. Prausnitz, J. Chem. Eng. Data, 2007, 52, 3

[70] J. Salminen, N. Papaiconomou, R. A. Kumara, J. M. Lee, J. Kerr, J. Newman and J. M. Prausnitz, Fluid Phase Equilibr., 2007, 261, 1-2

[71] P. Keil, M. Kick and A. König, Chem. Ing. Tech., 2012, 84, 6

[72] A. S. Amarasekara and O. S. Owereh, J. Therm. Anal. Calorim., 2011, 103, 3

[73] Z.-B. Zhou, M. Takeda and M. Ue, J. Fluorine Chem., 2004, 125, 3

[74] K. Kubota, T. Nohira and R. Hagiwara, J. Chem. Eng. Data, 2010, 55, 9

[75] J. R. Stuff, Thermochim. Acta, 1989, 152, 2

[76] C. S. Stefan, D. Lemordant, P. Biensan, C. Siret and B. Claude-Montigny, J. Therm. Anal. Calorim., 2010, 102, 2
[77]

L. J. Krause, W. Lamanna, J. Summerfield, M. Engle, G. Korba, R. Loch and R. Atanasoski, J. Power Sources, 1997, 68, 2

[78] K. Xu, Chem. Rev., 2004, 104, 10

[79] U. Domanska, Thermochim. Acta, 2006, 448, 1

[80] K. Tsunashima, S. Kodama, M. Sugiya and Y. Kunugi, Electrochim. Acta, 2010, 56, 2

[81] D. R. MacFarlane, S. A. Forsyth, J. Golding and G. B. Deacon, Green Chem., 2002, 4, 5

[82] J. D. Holbrey, W. M. Reichert, R. P. Swatloski, G. A. Broker, W. R. Pitner, K. R. Seddon and R. D. Rogers, Green Chem., 2002, 4, 5

[83] Z. B. Zhou, M. Takeda and M. Ue, J. Fluorine Chem., 2003, 123, 1

[84] H. Yang, G. V. Zhuang and P. N. Ross, Jr., J. Power Sources, 2006, 161, 1

[85] V. Kamavaram and R. G. Reddy, Int. J. Therm. Sci., 2008, 47, 6

[86] M. Blesic, M. Swadzba-Kwasny, T. Belhocine, H. Q. N. Gunaratne, J. N. C. Lopes, M. F. C. Gomes, A. A. H. Padua, K. R. Seddon, L. P. N. Rebelo and Gosia, Phys. Chem. Chem. Phys., 2009, 11, 39

[87] M. Y. Keating, F. Gao and J. B. Ramsey, J. Therm. Anal. Calorim., 2011, 106, 1

[88] J. Reiter, S. Jeremias, E. Paillard, M. Winter and S. Passerini, Phys. Chem. Chem.Phys., 2013,15,7

[89] A. K. Burrell, R. E. Del Sesto, S. N. Baker, T. M. McCleskey and G. A. Baker, Green Chem., 2007, 9,5

[90] J. D. Holbrey, K. R. Seddon and R. Wareing, Green Chem., 2001, 3, 1

[91] K. R. Seddon, A. Stark and M. J. Torres, Pure Appl. Chem., 2000, 72, 12

[92] G. B. Appetecchi, M. Montanino, D. Zane, M. Carewska, F. Alessandrini and S. Passerini, Electrochim. Acta, 2009, 54, 4

[93] G. B. Appetecchi, S. Scaccia, C. Tizzani, F. Alessandrini and S. Passerini, J. Electrochem. Soc., 2006, 153, 9

[94] R. L. Gardas, M. G. Freire, P. J. Carvalho, I. M. Marrucho, I. M. A. Fonseca, A. G. M. Ferreira and J. A. P. Coutinho, J. Chem. Eng. Data, 2007, 52,5

[95] H. Matsumoto, H. Kageyama and Y. Miyazaki, Chem. Commun., 2002, 16

[96] H. Matsumoto, T. Matsuda and Y. Miyazaki, Chem. Lett., 2000, 12

[97] M. Swadzba-Kwasny, L. Chancelier, S. Ng, H. G. Manyar, C. Hardacre and P. Nockemann, Dalton T., 2012, 41, 1

[98] H. Ohtani, S. Ishimura and M. Kumai, Anal. Sci., 2008, 24, 10

[99] S. D. Chambreau, J. A. Boatz, G. L. Vaghjiani, C. Koh, O. Kostko, A. Golan and S. R. Leone, J. Phys. Chem. A, 2012

[100] P. Wasserscheid and T. Welton, Ionic liquids in synthesis, $1^{\text {st }}$ Ed., Wiley-VCH, Weinheim, 2003

[101] S. Sowmiah, V. Srinivasadesikan, M.-C. Tseng and Y.-H. Chu, Molecules, 2009, 14, 9 
[102] M. Montanino, M. Carewska, F. Alessandrini, S. Passerini and G. B. Appetecchi, Electrochim. Acta, 2011, 57

[103] T. Welton and J. P. Hallett, Chem. Rev., 2011 , 111,5

[104] F. F. C. Bazito, Y. Kawano and R. M. Torresi, Electrochim. Acta, 2007, 52, 23

[105] N. De Vos, C. Maton and C. V. Stevens, ChemElectroChem, 2014, 1, 8, 1258

[106] Y. Ye and Y. A. Elabd, Macromolecules, 2011, 44,21

[107] J. N. A. Canongia Lopes and A. A. H. Padua, J. Phys. Chem. B, 2006, 110, 7

[108] A. Triolo, O. Russina, H. J. Bleif and E. Di Cola, J. Phys. Chem. B, 2007, 111, 18

[109] T. Koeddermann, D. Paschek and R. Ludwig, Chemphyschem, 2008, 9, 4

[110] I. Lopez-Martin, E. Burello, P. N. Davey, K. R. Seddon and G. Rothenberg, Chem. Phys. Chem., 2007, 8, 5

[111] M. A. A. Rocha, C. M. S. S. Neves, M. G. Freire, O. Russina, A. Triolo, J. A. P. Coutinho and L. M. N. B. F. Santos, J. Phys. Chem. B, 2013, 117, 37

[112] M. A. A. Rocha, C. F. R. A. C. Lima, L. g. R. Gomes, B. SchroÌder, J. A. P. Coutinho, I. M. Marrucho, J. M. S. S. EsperancÌ§a, L. s. P. N. Rebelo, K. Shimizu, J. N. C. Lopes and L. s. M. N. B. F. Santos, J. Phys. Chem. B, 2011, 115, 37

[113] M. A. A. Rocha, M. Bastos, J. A. P. Coutinho and L. M. N. B. F. Santos, J. Chem. Thermodyn., 2012, 53, 0

[114] N. S. M. Vieira, P. M. Reis, K. Shimizu, O. A. Cortes, I. M. Marrucho, J. M. M. Araujo, J. Esperanca, J. N. C. Lopes, A. B. Pereiro and L. P. N. Rebelo, Rsc Advances, 2015, 5, 80

[115] V. Nair, S. Bindu and V. Sreekumar, Angew. Chem. Int. Edit., 2004, 43, 39

[116] S. T. Handy and M. Okello, J. Org. Chem., 2005, 70,5

[117] P. A. Hunt, J. Phys. Chem. B, 2007, 111, 18

[118] T. S. Carlton and R. J. Winkle, J. Fluorine Chem., 1993, 65, 1-2

[119] Y. Yoshida and G. Saito, Phys. Chem. Chem. Phys., 2011, 13, 45

[120] G. D. Smith, O. Borodin, J. J. Magda, R. H. Boyd, Y. Wang, J. E. Bara, S. Miller, D. L. Gin and R. D. Noble, Phys. Chem. Chem. Phys., 2010, 12, 26

[121] O. Russina, F. Lo Celso, M. Di Michiel, S. Passerini, G. B. Appetecchi, F. Castiglione, A. Mele, R. Caminiti and A. Triolo, Faraday Discuss., 2013, 167

[122] T. Mizumo, E. Marwanta, N. Matsumi and H. Ohno, Chem. Lett., 2004, 33, 10

[123] S. Schneider, G. Drake, L. Hall, T. Hawkins and M. Rosander, Z. Anorg. Allg. Chem., 2007, 633, 10

[124] J. Palgunadi, S. Y. Hong, J. K. Lee, H. Lee, S. D. Lee, M. Cheong and H. S. Kim, J. Phys. Chem. B, 2011, 115, 5
[125] D. M. Drab, M. Smiglak, J. L. Shamshina, S. P. Kelley, S. Schneider, T. W. Hawkins and R. D. Rogers, New J. Chem., 2011, 35, 8

[126] M. J. Monteiro, F. F. Camilo, M. C. C. Ribeiro and R. M. Torresi, J. Phys. Chem. B, 2010, 114, 39

[127] H. S. Schrekker, D. O. Silva, M. A. Gelesky, M. P. Stracke, C. M. L. Schrekker, R. S. Goncalves and J. Dupont, Braz. Chem. Soc., 2008, 19, 3

[128] Z. B. Zhou, H. Matsumoto and K. Tatsumi, Chem. Eur. J., 2004, 10, 24

[129] Z. B. Zhou, H. Matsumoto and K. Tatsumi, Chem. Eur. J., 2006, 12, 8

[130] S. H. Fang, Z. X. Zhang, Y. D. Jin, L. Yang, S. Hirano, K. Tachibana and S. Katayama, J. Power Sources, 2011, 196, 13

[131] S. A. Katsyuba, M. V. Vener, E. E. Zvereva, Z. Fei, R. Scopelliti, G. Laurenczy, N. Yan, E. Paunescu and P. J. Dyson, J. Phys. Chem. B, 2013, 117, 30

[132] K. Shimizu, C. E. S. Bernardes, A. Triolo and J. N. Canongia Lopes, Phys. Chem. Chem. Phys., 2013, 15, 38

[133] S. Luo, S. Zhang, Y. Wang, A. Xia, G. Zhang, X. Du and D. Xu, J. Org. Chem., 2010, 75, 6

[134] H. Srour, H. Rouault, C. C. Santini and Y. Chauvin, Green Chem., 2013, 15, 5 